\title{
Banking globalization: from origin to development and internationalization
}

\author{
Rajeev Rana \\ Dept. of Economics, APB P.G. College, Augustmuni, Rudraparyag, Uttarakhand, India \\ Correspondence author email: rajeevjeet@gmail.com
}

\begin{abstract}
The globalization of financial markets has encourage internationalization of banking to finance cross-border trade and business, banks which was localized initially having their presence globally to provide financial services to their customer. There are several push and pull factor which had been encourage offshore banking activities as well as huge presence on global market. These banks in different counterpart may be known with different names i.e. investment banks, universal banks and global banks, and basically having almost similar nature of business but had been differentiated either due to the geographical identities, or on the basis of legal separation under the specific law. The paper have been explaining many reasons that why banks become global banks. Indeed, the individual banks decision to expand abroad are for multiple reasons out of which few are critical which encourage domestic banks to offer services globally. The objective of paper is also to see the growth of offshore claim, contingent liabilities and internationalization.
\end{abstract}

Keywords: Global banks, Cross-boarder trade, Foregin claims, Banking regulation

JEL Classification : G15, G24, G32.

\section{Understanding the nature of global banking}

Once banks go global and spread their activities abroad by offering various type of services to the global customers recognized as their internationalization with different names, a multinational banks, international banks, universal banking or global banks are termed interchangeably. To make clear distinction between these terms are very difficult. The connotation varies due to geographic diversity as in European counterpart banks offering services globally recognized as universal banks while in the U.S.A they recognized Investment banks, and other counterparts of the land they have been recognized as global banks.

The cross-border operation and services offered by those banks mostly similar and very less distinction have been found which limits them due to their own structural parameters, regulatory conditions. However, Lewis and Davis (1987), made some distinction of international banks and explain traditional foreign banks offer and involves in the transaction with non-residents in domestic currency to allow trade finance and other international transactions. In the Eurocurrency banking banks participating in foreign exchange transaction with both resident and non-residents.

Buckley and Casson (1999), define multinational banking as an enterprise which 'owns and control activities in different countries'. So any bank own and control branches or affiliates in more than one country and involves an elements of foreign direct investment (Jones, 1992), Robinson (1972), Gray and Gray (1981) recognized that international banking do not require physical presence offshore distinguish from multination banking. 
The forces that motivated the growth of multinational banking are expanding international trade, colonialism and the strength of the British Empire in early era of development. Which has been substituted by new source of funds, increasing competition due to gradual liberalization of domestic banking sectors in many countries (Huertas, 1990).

There have been many reasons that push domestic banks to become global banks. Indeed, the individual banks decision to expand abroad for multiple reasons out of which few are critical which encourage domestic banks to offer services globally. A banks go global to serve their domestic customers who have gone abroad- "the gravitational pull effect" that banks follow their domestic customers abroad to reduce the likelihood that they might lose their business to host-country banks (Metais, 1979). Indeed, each banks had a differentiated package of products, which sometimes give foreign banks advantage over domestic institution (Caves, 1977). banks headquartered in one country set up foreign subsidiaries in other countries or setup branch abroad- for as an entities banks maximize their own profits by providing services to as many foreign or domestic customers as possible, rather than looking at them as financial institutions that only move abroad when their domestic clients move abroad (Aliber, 1984). Dwenter and Hess analyzed banking theory based on asymmetric information between a bank and its customers, and concluded that banks' profits should differ between economic boom and busts (Dwenter ad Hess, 1998). These authors also suggest that one of the main reasons that explain expansion of banks globally in certain countries is due to protection that the legal systems of these countries offer to foreign financial institution (La Porta, 1977). For example Japan have laws that protect foreign banks, encouraging them to open branches in their counties.

Increasing competition in financial services and cross-border financial flows has result of less number of small banks operate in many countries, it also evident in different type of bank's including the mutual savings and cooperative banks as well as domestic commercial banks. However the number of foreign banks has increased in every banking market over the same period, reflecting the internationalization trend and the opportunities accessibility of trade and finance (Del Negro \& J.kay)

\section{Structural framework of international banking}

The banking globalization is evolving, moving away from one place to other with primarily cross-border flows and cross-border transactions with internationally diversified ownership of banks. However, apart from international transaction the growth of banking also took place due to growing size multiple transactions extended by the branches and subsidiaries of parent banks that are located in host country markets, derivatives and other forms of offshore investment have also push banking globalization. These implications are visible as the developments of services of globally-oriented banks remain epicenter towards host countries from the parent countries of the same banks.

The main type of frameworks use by international banking to operate globally due to that bank operates through holding companies or in branches or separately incorporated subsidiaries e.g. joint venture, special purpose vehicle, and simple representative offices (shell branch) because of Native or foreign tax or banking law favors operation though subsidiaries, and there might be other reason that host government does not permit foreign banks to have local branches. In which the parent banks seeks consumer business in the foreign market or it has specialized business that is facilitated by separate incorporation, apart from their most preferred option of foreign branches. Many of them banks also operate globally through separately capitalized foreign subsidiaries. As acquiring an established institution helps the gain in the term of sizable, presence in the market. Most U.S banks having their owned subsidiaries and controlled by the parent (J. V. Houpt and M.G. Martinson, 1982) as mention below. 
Banks operated internationally through foreign joint venture and were more popular in 1970s, when many U.S banks have begun to enter in an international banking. Joint venture banking growth begun with advantage of appealing partners both side domestically and in the abroad.

With basic structure and historical development, organizational structure, universal (Global) banks constitute multi-product firms within the financial sector. They target all segment of the variety of product for their client in the domestic environment and provide full range of appropriate financial services. However, outside the home market, at naïve they adopt narrower competitive profile with the help of technical collaboration with the host banking or expanding their services focusing on wholesale banking and securities activities as well as international private banking (I.Walter, 1997). The global banks have been recognized in the different name by different economist over the world. The nature and work of global banking are so wide, and include large investment activities, as well off-shore countries investment with international operation of variety of financial instrument.

Banks can be term as a global banks on the basis of their presence in the international market to finance trade, cross border flow of financial capital, stocks of cross-border claims that capture inter-country exposure (Camelia .M and Javier.A Reyes,2011), providing debt, investment in equity with wider financial markets, including investment in stock market, advisory, providing loan and management to foreign counterparts, offshore-branching, (Goldberg and Saunders, 1981) acquiring shareholding in a foreign bank (subsidiary) being "globalized". The process of globalization of banking nearly started in the 1970's onwards with the internationalization of banking (Pecchioli, 1983), following financial innovation a period of rapid innovation in the capital markets, complex product such a 'securitization' in the 1980 for two purpose one is to making loan tradable and second use of asset-backed securities for enhancing the growth through financial product and innovation and use of financial derivatives (W. Mullineux and V. Mirinde) which enhance banks' ability to generate liquidity and bringing down their cost to finance the rapid increase in international trade. Of which these international banking activities have reached in historical peak due to an increase in cross border mergers (Berger et al.2000)

Further, Kubelec and Sa (2010) conduct study of 18 advance emerging market and collected a large dataset of bilateral cross-border exposures by asset class (FDI, portfolio equity, debt, and foreign exchange reserves) to exhibit of financial interconnectedness over 1980-2005, and they prove that these financial network has become more clustered over the time and its central hubs are the United State and the United Kingdom. Comparison with the international trade network reveals that both networks have experienced increased connectivity over time, although it has been observed that financial openness increases much faster that trade openness.

The role of global banks is to reducing financing cost. In the broad sense global banks include all combination of activities performed by banks (i.e. acceptance of deposit, direct lending, investment in equity/debt, underwriting, insurance services trade financing etc.). The banking internationalization strongly emphasis on the three activities (i) providing loan \& asset-liability management to foreign counterparts, (ii) expanding and opening foreign branch and (iii) to acquire shareholding in a foreign banking as subsidiary

Bank has been transformed from domestic- to-international and international to multi-national then global or so called them Universal banking particularly in Europe, To understand the nature of global banking and their motivation why they go globally?, and focus the global market required topology linkage between among the agents, markets, institutions, and countries. (Caballero, 2010). Aliber (1993) define multinational model of global banking expands in form of its home market and sets up subsidiaries abroad that borrow locally to finance assets operates with sizeable foreign branches and subsidiaries 
in multiple jurisdictions (Jones, 1992) and those out of the home country through major financial center and conduct cross-border business explaining under international banking model and later 1980s all banks shifted towards multinational model banking.

The second age of globalization are known a resurgence of international banking, continuing general expansion of international financial integration (Obstfeld and Taylor, 2004). And the share of country banking systems of banks with sizable foreign positions have grown tremendously. Moreover, the form of banking globalization is evolving, moving away with cross-border flows to a system with both cross-border transaction and more internationally diversified ownership of banks. Beside diversified ownership pattern there are other type of international transaction has been increases that transaction extend by the branches and subsidiaries of parent banks that which were located in host country markets, as derivative uses and other form of international investment settle by banks (Obstfeld and Taylor, 2004). The broader objective in the global capital market integration has been detailed by Obstfield and Taylor (2004) with an empirical studies of Lane and Milesi-Ferretti (2001).

With this perspective of the parent banks spreading their international positions from the bank-specific to search yield and diversification opportunities. Beside from these two important factors other includes change in regulatory framework in the home of host countries market. Due to which there have been increase the accessibility of expanding services to the host country either in the form of cross-border transactions or either in the form of establishing branches and subsidiaries in the host countries. Even, it was observed that most of the cases foreign banking entry was previously restricted into foreign markets had increase due to which of the agreements made in conjunction with negotiations in the international trade and particularly specific forms of the market access.

Banks offer direct lending particularly to large scale borrowers such as states as well as to the multinational companies as mostly in the form of syndicated loans. Which usually do not require physical presence of the bank in the foreign nation. However, there are representative offices may prove useful for this operation. As foreign banking branches are the internal part of the parent bank which offers a range of a variety to banking services in both domestic and foreign customers. Traditionally, they concentrate their banking activities in the primarily wholesale market. And their subsidiaries have identical banking powers as domestic banks and are typically retail oriented.

Banks has grown in the part of central and Eastern Europe in the earliest of 1990s with experience of rapid growth of foreign ownership in local banking systems. In the earliest of $21^{\text {st }}$ century these foreign banks participation in the markets has been often increased about 80 percent of the local banking assets. In the experience of Latin American financial liberalization there was first wave of liberalization that follow your customer type during mid to late 1990s. The development of foreign banking branches including its subsidiaries during last 40 years remain largely uneven. Foreign banks branches considered as a mature form of expansion abroad. Brealey and Kaplanis (1996), suggested that the number of banks foreign branches has been increased very fast from 1960 to the mid-1980s and then slow down significantly after 1985. Later on it was also found that the number of cross-border merger and acquisition in the banking industry has risen most rapidly in the 1990s. Which was still a small fraction of the total banking M\&A activity within individual nations (Group of Ten, 2001) and they were rarer than in other industries (Focarelli and Pozzolo, 2001).

The banking internationalization has been explain by three major pillar explaining the pattern of internationalization and supported by the empirical literature also, where are: economics integration, institutional characteristics and profit opportunities. These are well-accepted fact in the economic literature that the pattern of bank internationalization was correlated with degree of integration between the home country of the parent company and the country where the branch or the subsidiary is located. 
Integration related both to strictly economic variables, such as the levels of trade or foreign direct investment, and to non-economic aspects, such a linguistic and cultural similarities.

The restriction imposed by regulatory mechanism have been severely affect banks that how banks shape their international activities. For example, governments may change the regulatory mechanism which may reduce the degree of cross-border acquisition or consolidation either in the form of directly or either by enforcing explicit limits on cross-border M\&As or in the form of blocking single takeovers. Also indirectly through failing to reconcile structural divergence between the financial systems, or in the form of imposing limits on domestic banking activity. However, the characteristics of these investment banking sector can also influence the favors of banks entry (Boot, 1999). For example it has been reasoned that governments might wish to have the largest institutions of their nations which were typical domestically owned. In that cases, government can be expect that in more concentrated markets the entry of foreign banks in the domestic market will be more difficult, because one single acquisition would imply the loss of a significant share to the advantage of foreign investors.

Another important aspect of banking internationalization may be profit opportunities, which is also the most basic factor that encourage banking to operating their activities in foreign market. These is a bank-specific factors which related to the characteristics of the banks country of origin of the investing bank, and also to the country of destination of the investment. In the bank-specific characteristics, the main factor of size has been consider most appropriate for the patterns of internationalization of banking. The studies and empirical literature suggested that larger banks are much more international than smaller ones. This is the case they have larger as well as more internationally located customers (Berger et al., 1995). Also they have been encourage more stronger incentives to diversify internationally and its portfolio and to smooth the effects of nonparallel fluctuation in the pattern of loans and deposits as they are involved in activities such as portfolio management and investment banking which are typically found in the international banking and by the characterized they have advantage of economies of scale and scope.

Within the domestic country assign those banks may have more potential of the banks internationalization in the reference of the development of the financial markets, and banks which are operating in developed market as they are seen to be more efficient and viable if compared. So, this is to hold a comparative advantage with respect to their competitors of the destination country (Boot, 1999). However, there is very less or almost no empirical evidence given in the support of evidence that on the importance, profit opportunities in the destination market of investment have been related to country risk (Grosse and Goldbreg, 1991: Fisher, and Moyneux, 1996; Yamori, 1998).

\section{Characteristics of the bank and of the country of origin}

The decision of banks to expand abroad is basically depends of the size of banks itself, as empirical studies suggested that larger banks likely to operate in both ways i.e. with foreign branches and foreign subsidiaries. In the same way banks having a larger share of non-interest income might likely to operate in foreign activates, may be due to advantage of innovation and their aggressive strategic behavior in the home as well as abroad activities. Those countries where banking seems to me more profitable business banks likely to explore more branches abroad, and push their supply and variety of product with specialized services including some more lucrative befits and offers. In sum-up those factors elaborating the characteristics of the bank and about the country of origin had been increased almost two times, the marginal effect in the case of number of branches roughly about 11.4 percent, and in the case of subsidiaries 5.1 per cent, explaining with the level of roughly with probabilities and approximately the same size. 
The evaluation of banking internationalization is moving away from the way of cross-border flows in a system of both cross-border settlement with the internationally diversified structure of ownership of banks. However, there are variety of international transaction also had been increased enormously, including transaction done by branches and subsidiaries of parent banks located in the host markets in the form of derivatives, and international investment done by banks.

The overall developments of these banking arena have profound significance in the host countries those are receiving global banking orientation, and the parent countries of these banks few implication that are immediately evident. For example related to the international transmission of shocks. Other implication are longer term and more structural by nature, such as those associated with productivity and technology spillovers, growth consequences, and institutional developments.

The impulse of globalization of investment banking varied differently in the form of player, time and form of country. Form the banks perspective, few sequence of enhance the international opportunities in global banking. However, few other sequences have regulatory changes in the home of the host country markets, which have increased the accessibility of expanding services to the host country, either as cross broader transactions or through establishing branches and subsidiaries in the host. Some cases of foreign bank entry into previously restricted markets have occurred in the aftermath of crises, or as a result of agreements made in conjunction with negotiations over international trade and specific forms of market access.

Particular episodes of expanding global banking include the period following the dissolution of the Soviet Union, when bank entry into central and Eastern Europe in the early 1990s let to a rapid growth of foreign ownership in local banking systems. By the early part of the $21^{\text {st }}$ century, foreign participation in the markets often exceeded 80 percent of local banking assets. Another episode of expansion occurred with the liberalization of financial sector in Latin America through the mid to late 1990s. The first wave of liberalization was a follow your customer type, taking place in the aftermath of expanded FDI into manufacturing and resource extraction industries and enhanced competition that Latin American countries faced form Asian counterparts. Another burst of foreign banking activity within Latin America occurred as result of financial crises of the mid-to-late 1990s.

The US and Spain were particularly active in their expansion into foreign market during this period and measured in terms of value of positions or numbers of acquisitions. Indeed, the result was substantial in roads into central and South America, as well as into Mexico by both U.S and Spanish parent banks. By Contrast, as we further elaborate that the next most active group of banks in mergers and acquisitions were the U.K. banks and those from other euro-area countries. These banks took a regional focus, with targeted positions that were more concentrated across industrialized and developing Europe.

\section{Globally-oriented banks, cyclical lending, and international linkages}

Once banks has its presence globally, or banks internationalization has been spread there are huge possibilities that transmission of shocks increased across the global market as it banking internationalization affect business cycles. Practically, it has been experience that global banks are the agent of international risk sharing, diversification of risk, and financial intermediation, though which host courtiers depends on served through cross-broader flows or in the host markets by branches and subsidiaries of the parent banks.

It is equally important to understand that how basically the banking internationalizing structure or ownership of global banks affect the business cycles and its international linkages. The studies have been suggested that banking internationalization has net effect on business cycles in different ways. First, in the macro 
banking model suggested by Morgan, Strahan and Rime (2004). Which has implication on relaxed restriction on cross-baking within the U.S.A integration have severely dampen the banking capital shock within borders, but amplifies the effect of bank-specific shocks across borders.

Banking foreign claims have increasing continuously including cross-broader claim and derivatives contracts, guarantees, and credit and other commitment. The table shows of BIS statistics that how banks are engaging in the foreign claims and other potential exposure

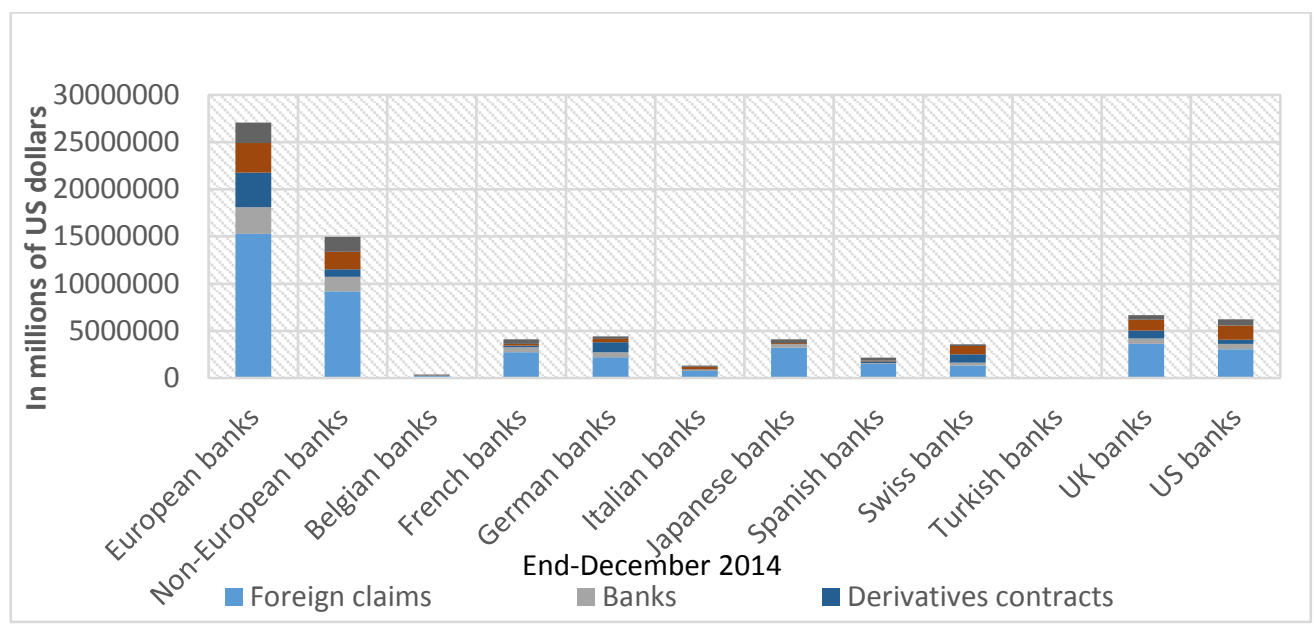

Figure 1. Consolidated foreign claims and other potential exposures

Source: consolidated banking statistics of BIS, 2014.

A cross-border activities encourage banks to shift from their cross-border activities to multinational banking with more local and likely locally funded operation. Another facts came to know that banks had reduced the number of subsidiary they hold abroad both includes advance and emerging market economics, while the total number of branches has risen sharply. But both subsidiaries and branch had been reduced in the wake of the global crisis and have continued to decline.

There are significant distinction have been identified between foreign claims and international claims which can be classified as:

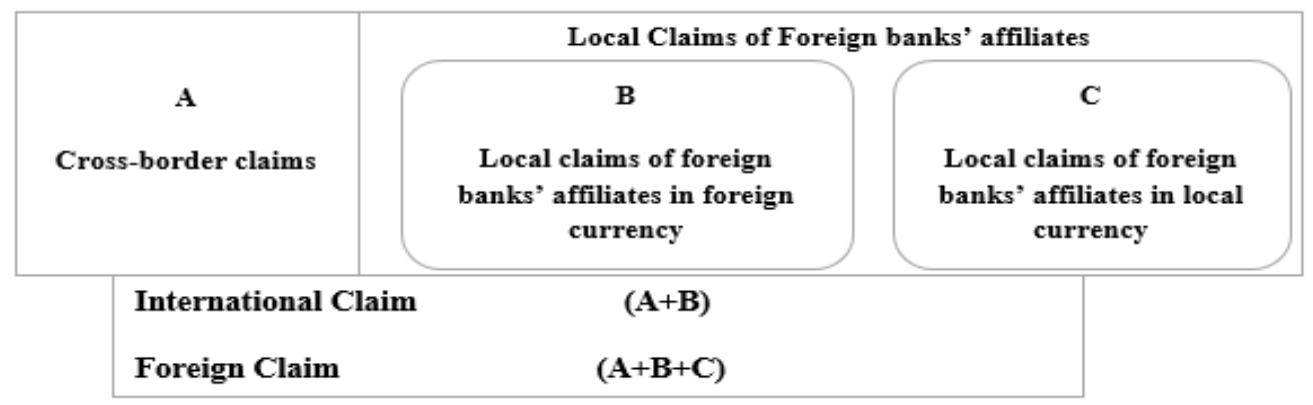

Figure 2. Types of clams in Bank for international settlements, consolidated statistics

Source: Cerutti. Claessens, and McGuire 2012.

A basic observation is that the availability of loanable funds via the deposit base contributes to pro cyclicality. If foreign -owned bank entrants are less reliant on hostcountry funding sources and more reliant on foreign sources that are their domestically owned counterparts. The pro cyclicality of their supply of loanable funds may be lower. 
The various banking studies suggest banking internationalization encourage cyclical lenders similar to domestic banks in the countries, which has been empirically verified in the case of Chile, Argentina and Colombia as the lending cyclical of foreign banking and their own private banks are almost similar. Essentially in the case of foreign banks came in the host countries through the acquisition of local banks, the M\&A activities of those banking studies have been suggested Crystal. Dages, and Goldberg (2001). However, the finding are different across the banks but strongly supported in the case of existing banks are either foreign owned or domestic owned. In such case when foreign banks has high growth of loan then they avoid the volatility form local financial systems in the way of destabilizing lenders.

Role of baking or banks internationalization in has been analyses though bankseccentric data which results to the studding the consequences of foreign versus domestic owned banking pattern for international cyclical and linkages. The literature strongly expressed the role of foreign-owned banks as an agent of transmission of monetary policy as well as interest rate shocks in the various national and international markets. Similar studies have been supported in the evidence of banks internationalization that Japanese banks also transmitted shocks which later hit their own capital base and directly affect their baking stock price moments into the U.S. real estate market through Japanese banking and their subsidiaries having their operation in U.S. the concrete demonstrate of transmission through individual U.S. bank is supported by those who examine individual bank balance sheet data for all U.S.

Banks is instituted by those who are closely examine individual bank balance sheet data for all U.S. banks with global operation between 1980 and 2006 (Cetorelli and Goldberg (2008)). This analysis, which also considers the effect of banking globalization on the lending channel within the U.S. demonstrates that not only is the lending of foreign offices of U.S. banks affected by U.S. monetary policy, but these foreign offices can rely less on support from parent bank balance sheets in times of tighter liquidity condition in the U.S.

\section{Factors that encourage banks for globalization}

There are several factors that encourage internationalization of banks and broadly can be classified in two phase: one push factor: factor involves a force which acts to drive banks away from a native country. Second as a pull factors: what draws banks to a new location (i.e. what attracts to the banks globally).

Table 1. Why banks go abroad and become global banks

\begin{tabular}{|c|c|}
\hline $\begin{array}{l}\text { Push Factor: factor involves a force which } \\
\text { acts to drive banks away from a place. }\end{array}$ & $\begin{array}{l}\text { Pull Factors: what draws banks to a new } \\
\text { location. }\end{array}$ \\
\hline Macroeconomic Factor. & Search for yield (profitability). \\
\hline $\begin{array}{l}\text { Policy environment (i.e. liberalized policy } \\
\text { or banking reforms by host countries). }\end{array}$ & Cyclical lending and International Linkages. \\
\hline $\begin{array}{c}\text { Allowing competition by banks } \\
\text { domestically. }\end{array}$ & Cross-border lending activities. \\
\hline Institutional developments. & Liquidity or Global Liquidity. \\
\hline Diversification Opportunities. & $\begin{array}{c}\text { OTC derivative and Interest rate derivatives } \\
\text { contracts. }\end{array}$ \\
\hline $\begin{array}{c}\text { Agreement under the International Trade } \\
\text { Treaty of Market Access. }\end{array}$ & $\begin{array}{c}\text { Risk Transferring or risk minimizing } \\
\text { strategies }\end{array}$ \\
\hline $\begin{array}{l}\text { Merger \& Acquisition and Takeover of } \\
\text { domestic banks by foreign banking entities. }\end{array}$ & $\begin{array}{l}\text { Stability during financial crises compare to } \\
\text { narrow domestic banking activities. }\end{array}$ \\
\hline Access to Bail-Out during the crises. & Scope of Economics and X-Efficiency. \\
\hline Economic Integration & Market Innovation \\
\hline
\end{tabular}

Source: Research finding from various studies 
The list has been shown that why bank globalized and several important factor constitute for their globalization process, even if they do not go abroad they have sever thereat in term of losing their clients domestically those who went abroad and secondly, they have been either takeover or thrown out by big banks in the term of merger \& acquisition activities. Going banks globally is win-win situation in such case as they are able to serve their clients globally but also they have diversification of business, more profit opportunities, innovation and large market shares with least cost or achieving higher efficiency in term of serving to the global client.

\section{Structure of the global banks}

The Table 2. Represent the anatomy of global banks and their different structure in the various forms which shows that globalization of banks have been shaping in the different structure, particularly due to domestic regulation and law in the home land of country. The internationalization of banking structure have been classified in the four category.

The specific structures that universal banks adopt are driven by regulatory consideration, by the production-function characteristic of financial services, and by demand-side issues relating to market structure and client preferences. American regulation, for example, mandates a Type D form of organization, with the Glass-Steagall provisions of the Banking Act of 1933 and later the Gramm-Leach-Bliley Act of 1999 requiring functional separation of banking and insurance (taking deposits and extending commercial loans) and most types of securities activities. Each type of business must be carried out through subsidiaries under a qualified holding company structure. British universal banking follows that the Type $\mathrm{C}$ model, with securities and insurance activities carried out via subsidiaries of the bank itself. Most continental European countries seem to follow the Type B model, with full integration of banking and securities activities within the bank itself (despite functional regulation), and insurance, mortgage banking and other specialized financial and non-financial activities carried out through subsidiaries. As noted, the Type A universal banking model, with all activities carried out within a single corporate entity, seems not to exist even in environments characterized by a monopoly regulator such as, for example, the Monetary Authority of Singapore.

Table-1.2. Structure of the global banks.

\begin{tabular}{|l|l|l|l|}
\hline No. & Nature & Global Banks: activities & Structure \\
\hline Type-A & Full Integration & Banking activities & Mecurities activities \\
& & Insurance activities & \\
& & Other & \\
\hline Type-B & Partial Integration & Banking activities including & European Banking \\
& & securities, commercial and & E.g. Deutsche Bank \\
& & investment banking & A.G. \\
& & Insurance activities & \\
& & Assets Management & \\
& & Mantgage banking (subsidiary) & \\
& & Banking activities including & British Banking \\
& Structure & commercial banking & E.g. Barclays plc. \\
& & Subsidiaries activities in & \\
& & Securities, Insurance and & \\
& & Financial services. & \\
\hline Type-D & Holding Company & Subsidiary activities in: & American Banking \\
& Structure & Banking, Securities and & E.g. Citigroup. J.P. \\
& & Insurance. & Morgan Chase \& co. \\
\hline
\end{tabular}

Source: banking structure and function, Ingo Walter. 
From a production-function perspective, the structural form of universal banking appears to depend on the ease with which operating efficiencies and scale and scope economics can be exploited-determined in large part by product and process technologies as well as the comparative organizational effectiveness in optimally satisfying client requirements and bringing to bear market power.

\section{European universal banking how it's different from U.S originating banks}

Banking have been classified on the basis of nature, activities, area \& scope. They have also been categorized by their foreign operation, investment activities, engaging in insurance then normal banking activities. In U.S under the rugged law "The Glass-Stegal Act-1933" made separation between banking activities or their line of business.

The Glass-Stegall Act which brings significant changes in the American banking then the other banking structure particularly European banking. Before the Act came All Banks and Financial Institution are in U.S engaged in all financial services beside their core banking activities they may sell insurance, underwrite securities, advisory, diversified investment and carry out securities transaction on behalf of clients (Benston. 1994). The Glass-Stegall act made separation of banking on the ground of their activities. Banks who engaged in core banking activities (i.e. accepting deposit, lending and primary banking) or fiduciary services not permitted to engage in to sell insurance, underwriting of securities and to offer financial services.

To offer variety of financial services including investment activities, merchant banking, insurance, mortgage banking are now permitted to only specialized banks known as an Investment banks. Thus the primary Laws of Glass-Steagall Act or called National Banking Act prohibits commercial bank and investment banks on the basis of the activities of business and offering full range of financial services.

However, it has been observed that U.S. banks are permitted to offer full verities of services before the act came and later on 1900 under the Gram-Lichie-Belly Act, and National Banking reform act (1956) permitted commercial banks to engage in financial services as till now they were prohibited as these services could be provided only by investments banks.

The state of international baking can be examined in two ways: (1) by looking at the number and size of offices of different types:-for example, the assets of foreign branches, subsidiaries, and other foreign offices and the volume of internationally related credit extended directly from the head office. And (ii) by reviewing data on total credit exposure to foreign parities, by country. Thus here we look the number of foreign branches to examine the structure for international banking by U.S banks is in large part a reflection of efforts to restrain banking power throughout this country's history, government policy has sought to restrain concentration in banking and other financial activities. Until 1997, U.S banks generally were not allowed to branch across state lines (although, by then their parent holding companies could own banks in different states) and barred from underwriting corporate securities and from conducting other financial activities typically permissible for foreign banks.

Although the U.S banking main structure for international banks were unique in the term of bank holding and offices used by U.S foreign banks in the various forms (e.g. branches, subsidiaries, etc.) to provide international banking services. The graph shows growth of foreign U.S banking growth during the 1970s to 1998 period how U.S banks operate internationally, and most of the foreign counterpart are wholly owned by U.S banking parent. 


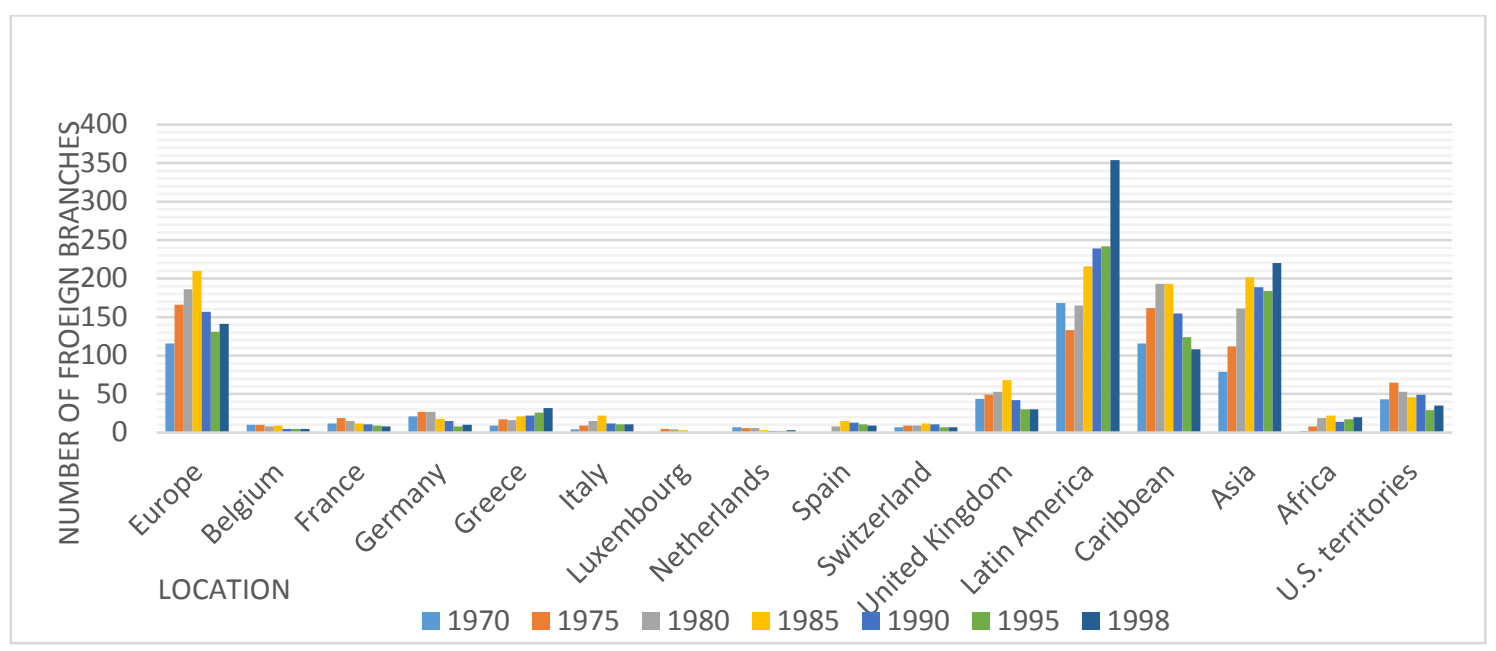

Figure 3. Number of foreign branches of Federal Reserve member banks, by location, selected years, 1970-98

Source: James V. Houpt, International Activities of U.S. Banks and in U.S. Banking Markets.

In the federal republic of Germany a credit institutions engage in all types of business typically commercial and investment banks, insurance and mutual funds activities classified as a universal banks since late 1850s. and they were not restricted to the limited scope of banking as in earlier U.S commercial banks was but apart from providing traditional services of 'accepting deposits and making advance', they were engaged in a diverse kind of banking and financial business including insurance and housing finance activities and categories as financial conglomerates, as a part of financial supermarkets (Gurusamy, 2009).

In Europe and particularly the Germany the financing done by German universal bankers (kredit banker) to the large-scale industrial financing and referred to the jointstock or credit banks structure. These banks operate national wide branching networks and provided an unrestricted rage of financial services including lending, underwriting, trust services and deposit banking. After European Unification banks operated nationwide along with branch networking, provide full range of financial services beside basic services, (i.e. commercial banks and investment banking operation), trust services, investing in the firm's shares, and advisory by a single commercial banks known as Universal Banks (Charles w. Calomiris, 1995).

\section{CONCLUSION}

Banks had been globalized based on their nature and activities which includes cross-borders transaction and flows, and also their diversified ownership structure has been recognized as bank internationalization. However, they have been called with different name due to several reasons, since in early period to now banks have been spread across the region and sectors to offering their services to their clients. Studies suggested that it is not only the reason to whom banks have been globalized beside their core activities i.e. searching for yield, cross-broader lending there are several technological innovation and market integration development took place which encourage banks to globalized and if they are not to be globalized they somehow threaten in the wake of merger and acquisition activities by other big banks. So even domestic or states banks if they get the opportunities to render services to their client has gone globally.

Once banks become international or global they provide the several benefits to their customer in different ways i.e. low transaction cost, high liquidity, easy access of 
borrowing and lending. This represent that once trade opportunities encourage between the nation's banks also move to the other nations for providing trade facilities, fast settlement and discounting the business opportunities with the objective to minimizing cross-border risk. The presence of banking globally had been changed from their origins as earlier banks used to show their presence in the form of shell banking, opening their affiliates, or subsidiaries and in other forms such as representative offices, Joint Ventures has been substitute by branches, acquiring domestic banks in the host countries or in the form of subsidiaries are the twenty first century global banks.

The strong expansion in banks internationalization in recent periods have been changed the shape of the global banking industry. These banks particularly follow their activities abroad: (i) to provide loans and asset-liability management for foreign counterparties. (ii) Opening as a foreign branch with acquiring shareholding (i.e. subsidiary). The declining trend have been capture of branch banking during the 1990s, in Europe except (such as Germany, Italy and Spain) where branch of banks have proliferated during 1990's mainly due to removal of branching/territorial restriction that were in place. Most of the European banking characterized by a declining number of banks, although most systems have a large number of small local and regional banks.

We have explain several factors that why banks go globally, primarily the objective is to find the profit opportunity. While the others important factors of globalization of banks have been classified into two broad category. First, push factors are those factors which involves a force which acts to drive banks away form a place, and secondly, pull factors are those factors: which draws banks to a new location. These two have been explained important factors that encourage banks to be globally and become global banks.

There are some debates for internationalization of banks that host country augmented with higher growth and better technology transfer from the foreign banking and they also benefited in term of wages, as the expansion of human capital should manifest in a greater worker productivity with rewarded by higher wages. Studies on banking FDI conclude that growth may occurred in both through technological transfer and through improved intermediation of capital flows between savers and investment opportunities.

These global banks are also subject to transmission of business cycles as the international trade theory suggested that trade are heavily influence through the transmission of cycles. In banking, once the internationalization took place they faced sever transmission of business cycles with growth and depression and further spread contagion across the markets. Then these global banks are immediately evident of international transmission of shocks.

While in the optimism of business cycle, the global banks are to encourage for the development in term of long term structural change associated with productivity and technology spillovers and institutional development. Global banks are also play important role for the regional and international capital market development with integration, which have been empirically proven that the development of banks globally integrated with the growth of capital market. These global banks playing more stabilizing role in the host credit market during the crisis.

\section{REFERENCES}

Adrian E, Tschoegl (1983). Size, Growth, and transnationality among the World's Largest Banks. The Journal of Business, Vol.56, University of Chicago Press.

Alan McIntyre and C, Chandrasek. International Banking Strategy: The quest for El Dorado? Oliver Wyman.

Aliber, Robert A (1984). International Banking: A Survey. Journal of Money, Credit and Banking and Growth. Vol. 16, No.4. Cambridge University Press 2004, Cambridge. 
Andrew W. M. and V. Murinde (2003). Handbook of International Banking. Edward Elgar Publishing Limited.

Ball, C.A. and A.E. Tschoegl (1982). The Decision to Establish a Foreign Branch or Subsidiary: An Application of Binary Classification Procedures. Journal of Financial and Quantitative Analysis.

Berger. A., DeYoung, H. Genay, and Udell. (2000). The Globalization of Financial Institutions: Evidence form a Cross-Border Banking Performance, BrookingWharton Paper on Financial Service 2000.

Berger. A., Kashyap. A, and Scalise J. (1995). The Transformation of the U.S. Banking Industry: what a long, strange Trip it's been, Brookings Paper on Economic Activities.

Boot, A.W.A (1999). "European Lesion on Consolidate Banking”, Journal of Banking and Finance, 23, pp. 609-613.

Brealey. A, Kaplanis. E. (1996). The Determination of Foreign Banking Location, Journal of International Money and Finance.

Buch. M. (2000). Why Do Banks Go Abroad? Evidence form German Data, Journal of Financial Markets, Instruments and Institutions, 9, pp.33-67.

C, Minoiu and Javier A. Reyes (2011). A network analysis of global banking: 1978-2009. IMF Working Paper Series.

Charles W. Calomiris (1995). The Costs of Rejecting Universal Banking: American Finance in the German Mirror, 1870-1914. University of Chicago Press.

Charles W. Calomiris (1995). Universal Banking and the Financing of Industrial Development. The World Bank Policy Research Department.

Claudia M. Buch (1999). Why Do Banks Go Abroad? Evidence from German Data. Kiel Working Paper No. 948, Kiel Institute of World Economics.

D, Focarelli and A, Pozzolo (2002). Where do banks expand abroad? An empirical analysis. Economics \& statistics discussion paper. University of Molise and Ente Luigi Einaudi.

D, Quinn, Martin S, and A. Maria (2011). Assessing Measures of Financial Openness and Integration, IMF Economic Review.

Detragiache, Enrica, and Poonam Gupta, 2004, "Foreign Banks in Emerging Market Crises: Evidence from Malaysia,' IMF Working Paper 04/129 (Washington, International Monetary Fund).

G, Galati and Moessner (2011). Macroprudential policy - a literature review. Monetary and Economic Department of the Bank for International Settlements Working Paper.

Georg Rich and Christian Walter (1993). The Future of Universal Banking. Cato Journal, VoL 13, No.2.

Goldberg. L, Grosse. R. (1994). Location Choice of Foreign Banks in the United States, Journal of Economics and Business.

Goldberg. L, Johnson D. (1990). The Determinants of U.S. Banking Activity Abroad, Journal of International Money and Finance, 9, pp.123-37.

H. Grubel (1977). A theory of Multinational Banking. Quarterly Reviews, Banca Nezionale Del Lavoro.

H.E. Boschegn. (1979). the universal banking system in the Federal Republic of Germany. Journal of Comparative Corporate Law and Securities Regulation, North-Holland Publishing Company.

Henry S. Terrell and Sydney J. Key. (1970). the Growth of Foreign Banking in the United States: An Analytical Survey. The International Corporation, ed. Charles P. Kindleberger (Cambridge: M.I.T. Press.

Igno Walter (2009). Universal banking and shareholder value: a perspective. New York University and INSEAD. 
Jaime, Caruana. August (2012). International monetary policy interaction: challenge and prospects, Bank for International settlement.

Kevin J. Stiroh (2002). Diversification in Banking Is Noninterest Income the Answer? Federal Reserve Bank of New York.

La Porta, R., F. Lo'pez-de-Silanes, and A. Shleifer, (2002). “Government Ownership of Banks,' Journal of Finance, Vol. 57, No. 1, pp. 265-301.

Lewis, Davis and Mervyn (1987). Domestic and International Banking. MIT Press.

Linda S. Goldberge. (2007). Financial Sector FDI and Host Countries: New and Old Lessons, FRBNY Economic Policy Review.

Linda S. Goldberge. (2009). Understanding Banking Sector Globalization. Vol. 56, No. 1. IMF Staff Papers.

M, Hattori and Suda. Development in a cross-border bank exposure "network". The BIS international financial statistics.

M, Obstfeld and A. M. Taylor (2003). Globalization and Capital Markets. University of Chicago Press.

Maurice Obstfeld and Kenneth Rogoff (2009). Global Imbalances and the Financial Crisis: Products of Common Causes, University of California, Berkeley, and Harvard University.

McCauley, McGuire, Peter. (2010). the architecture of global banking: from international to multinational? BIS Quarterly Review.

McCauley. Ruud and D Wooldridge (2002). Globalizing international banking. BIS Quarterly Review.

Minsky, H.P (1994). Outline for Issues in Bank Regulation and Supervision. Paper 73. Levy Economics Institute of Bard College, N.Y.

Neil M C, Martin, Yeung Peter and J Henderson (2004). 'Globalizing' regional development: a global production networks perspective.

Norman S. Fieleke.The Growth of U.S. Banking Abroad:-An Analytical Survey. Federal Reserve Bank of Boston.

Obstfeld, Maurice and Alan M. Taylor (2004), Global Capital Markets Integration, Crisis,

Philip R. Lane, and Milesi-Ferretti (2008). The Drivers of Financial Globalization. New Perspectives on Financial Globalization (AEA).

R.E. Caves (1971). International Corporation: The Industrial Economics of Foreign investment. Economica.

Romer, P., 1993, 'Idea Gaps and Object Gaps in Economic Development,' Journal of Monetary Economics, Vol. 32, No. 3, pp. 543-73.

Sandra E, Leonardo G, and B Hofmannx (2013). Understanding Global Liquidity. Working Paper 402, Monetary and Economic Department, BIS.

Stefano Battilossi (2000). Financial innovation and the golden ages of international banking: 1890-1931 and 1958-81. Financial History Review 7.

Stijn Claessens and Neeltje van Horen (2012). Foreign Banks: Trends, Impact and Financial Stability. Research Department, IMF Working Paper.

Timothy W. Guinnane (2001). Delegated Monitors, Large and Small: The Development of Germany’s Banking System, 1800-1914. Journal of Economic Literature, Yale University.

Turner, P., 2006, “The Banking System in Emerging Economies: How Much Progress Has Been Made?'” BIS Paper No. 28.

W. Grais, and Z. K (2003). World the Changing Financial Landscape: Opportunities and Challenges for the Middle East and North Africa, World Bank Policy Research Working Paper 3050. 